Research Article

\title{
LAND CONFLICT RESOLUTION: CASE STUDY IN SARIREJO VILLAGE
}

\author{
Juniaty D. Aritonang*, Hidayat, Fikarwin Zuska \\ Department of Social Anthropology, Universitas Negeri Medan, Indonesia
}

Article history:

Submission December 2021

Revised December 2021

Accepted December 2021

*Corresponding author:

E-mail:

aritonangjuni@gmail.com

\begin{abstract}
This study aims to describe the factors that cause land conflicts between the community and the Air Force in the Indonesian Air Force in Suwondo and the strategies that the community uses in demanding their land rights. The author chose a qualitative approach with the ethnographic method to understand more deeply what is behind an event that took the process, causes and conflict resolution. The results showed that the factor causing the conflict was the claim of each party to the land. Conflict resolution efforts are carried out by the community to obtain land rights through non-litigation advocacy processes and litigation advocacy. The results of these two strategies were able to encourage the government to restore community rights to their land even though it had to go through a long struggle. In July 2020 the government issued a policy to move the Sowondo Base to Langkat Regency.
\end{abstract}

Keywords: -

\section{Introduction}

As one of the natural resources, land plays a very important role. Humans are of course very dependent on land. Not only farmers, but also other components of society, Philosophically, the existence of land is actually very closely related to humans. The rapid development of humans from time to time has resulted in various consequences. One of them is the need for land which is increasing day by day, both in terms of housing and for other purposes and needs. Meanwhile, on the other hand, land also for some members of the community has both social and economic functions.

In the past, what stood out was the social function of land, but since the rapid development activities, the function of land has shifted, and emphasizes the economic and political sides. In some parts of our society, land is also a status symbol which has cultural significance. If their status is disturbed, they will not hesitate to defend it with all their might. On the other hand, human existence increases while land as a source of life is limited. In other words, the existence of land in subsequent developments is increasingly significant, causing conflict.

The causes of conflict are found in human nature itself. Hobes described the mechanical model of man as motion. The heart is nothing but a spring, nerves are networks, and screws are the wheels that move the body (Saifuddin, 2006). Basically, conflict is a social phenomenon that is often present in the midst of human life. In fact, conflict has become an inseparable

\section{How to cite:}

Aritonang, J. D., Hidayat, \& Zuskal, F. (2021). Land Conflict Resolution: Case Study in Sarirejo Village. Indonesian Journal of Social Science Research, 2(2), 119 - 127. doi: 10.11594/ijssr.02.02.09 
part of people's lives and even a product of social relations. The conflict as a dispute about values or demands regarding status, power, and sources of wealth from insufficient supply (Limbong, 2012).

Social conflict is a product of social relations which can be divided into 3 types: first, cultural conflict (cultural violence); second, structural conflict (structural violence); third, violent conflict (direct violence). Meanwhile Koentjaraningrat (1984) stated that conflict can occur when: 1) competition between two or more ethnic groups in terms of obtaining the same livelihood field. 2). There is an imposition of cultural elements on the residents. 3). Forcing other ethnic groups with different religions to adhere to a certain religion. 4) Efforts to dominate other ethnic groups politically. 5). There is a hidden conflict between ethnic groups who are hostile to custom. In this case it is related to the study to be conveyed regarding the first thing.

The author's interest in studying land conflicts is due to the high incidence of land conflicts in Indonesian territory from year to year. Especially in the province of North Sumatra. Data from the Agrarian Reform Consortium (KPA) in 2019 there were 279 agrarian conflict eruptions with a conflict area of 734,239.3 hectares. The number of people affected by agrarian conflicts is 109,042 families spread across 420 villages, across all provinces in the country. North Sumatra alone contributed 24 cases. One of them is the research that will be reviewed in this paper (Arumingtyas, 2019).

The study of land conflicts in Indonesia, especially in North Sumatra, even though it had occurred before the 19th century, has developed a character and pattern. It hasn't even shown any significant signs. Seeing the land problems that occur shows how complex the problems are, so that cases that have arisen since the Dutch era have not been resolved until now. This is a historical fact that cannot be denied. The land problem is getting higher along with the rapid development while the root problem is not resolved. Various development practices that exist today and almost occur in all parts of Indonesia show the same patterns.
The reasons for the agrarian conflict are the granting of concession permits by the government through a ministry that specializes in forestry; the existence of manipulation of land acquisition for large-scale development; the entry of community land concessions within the company's territory (Rachman, 2013). Still according to him, resolving agrarian conflicts cannot be solved by patchwork. Just to solve it on the surface, but the root of the problem that occurred was not resolved.

As mandated in the Indonesian Constitution in the 1945 Constitution Article 33 paragraph 3, which states that the earth, water and natural resources contained therein are controlled by the state and used for the greatest prosperity of the people. In fact, this article implies that there is a prohibition on control of natural resources in the hands of a few people. In other words, monopoly is not justified. However, the current facts apply in business, business and investment practices in the field of natural resource management which are contrary to the principles of Article 33 of the 1945 Constitution. The government as an actor running the state has the right to control natural resources which are common law resources. Where every citizen has the right to agrarian resources without exception. Furthermore, Law No. 5/1960 concerning Basic Agrarian Principles, Article 2 and its explanation, states that the definition of "controlled" by the State does not mean "owned", but rather the right that gives the State authority to control as mentioned above (Chandra, 2019). However, this is what is often misused and is free to issue permits to entrepreneurs or third parties.

Land conflicts or what is more commonly called agrarian conflict occur because of the behavior pattern of agrarian inequality, natural resource management that is still messy and the paradigm used is capitalistic economic growth. One way out of the chaos that causes agrarian inequality, what is mandated in the MPR Decree No. IX of 2001 concerning Agrarian Reform and Natural Resource Management is actually not implemented. One of the mandates of this provision is to assign the House of Representatives together with the President to immediately regulate further on the implementation of agrarian reform and managing natural 
resources by making this provision the basis for any policy making (People's Consultative Assembly Republic of Indonesia, 2020).

The agrarian conflicts that occurred in North Sumatra were dominated by the plantation sector. Starting with the era of the tobacco plantation pioneered by Jacob Niehuys, intense land hunting was carried out to expand the plantation area. In 1863, Nienhuijs acquired 4,000 bau or 75 hectares of land which was used by erfpacht for 20 years. Then, Deli started and continued to be looked at after the first harvest on the second trial of tobacco cultivation, which was of very good quality and was accepted in the Dutch Roterdam auction market.

This study tries to describe the land conflicts that occur in the infrastructure and property sectors that occur between the Sarirejo community and the Indonesian Air Force, Sowondo Air Force. Sarirejo Village is a semiurban area located in Medan Polonia District, North Sumatra Province. The cause of the conflict was the claim of the Indonesian Air Force against the settlements occupied by residents. The residents have won the land dispute through a decision of the Supreme Court (MA). However, the TNI did not acknowledge this decision by unilaterally changing the name of Jalan Sarirejo to Ksatria.

The land in Sarirejo village was a Deli Sultanate's land that as wide as $770 \mathrm{Ha}$ of the land, was contracted out to Poland in two-terms contract for 75 years in 1880. After the contract expired, the land was diverted to tobacco industry with the name of "Langkat Asosiasi" and then sold to Deli Maatschappij, a trading and distribution company in the timber, construction product, and tobacco industries. After Indonesia independence in 1945, the industry was no longer operational until 1950. After that, the locals started to work the land, yet at the same time Deli Maatschappij requested the Deli Sultanate to build Polonia Airport. There were many riots and hunger strike in those years, forcing President Soekarno issued an emergency legislation No 1. Year 1951 to forbid the work of ex-plantation's land by locals (Ikhsan, 2015).

To ensure the nationalization of Dutch company or transfer of ownership of Dutch-owned company to Indonesia, the Law No. 86 Year 1958 about the Nationalization of Dutchowned Company was made and the process was enforced by the national army. Since then, the land of Sarirejo village and around the Polonia (ex-airport) was under the National army and the Indonesian Air Force (Naibaho, 2020).

The conflict of the Air Force and the Sarirejo locals, which were happening since 1970s, was started by the part of the Airforce that collect tax for the local produce, forbid any building to be built in the land, destroy the built homes, capturing and intimidating the locals, and forbid the locals to bury their deceased in their land. One time, they also enacted a military training in the local's settlement using blank bullets. Due to the continuous harassment, the locals filed a lawsuit against the Air Force at 1989 for the ownership of the land, and the local Court won some of the locals' lawsuit.

However, in efforts to resolve agrarian conflicts, the maximum impact can be made through community empowerment-based conflict resolution efforts (Nulhaqim, Fedryansyah, and Hidayat, 2019). What distinguishes this research from previous research is that this research focuses on efforts to resolve land conflicts between the community and the Sowondo Air Force that occurred in Sarirejo Village. Where the community uses two approaches at once in fighting for their land. Namely in litigation (through court channels) and non-litigation (through advocacy channels outside the court).

This research is important because it is one of the major land conflicts in North Sumatra whose resolution is not yet clear. In addition, this case has become a serious concern of President Jokowi to be resolved immediately because it is considered an obstacle to development in North Sumatra (Alexander, 2020). In March 2020 the Government issued a policy to resolve the conflict. However, de jure, the community was not yet fully legal as the owner of the land. This research is expected to provide useful information for readers, especially those involved in community empowerment and policy makers.

This study aims to try to describe what caused the land conflict that occurred between the community and the Indonesian Air Force at 
Suwondo Air Force Base in North Sumatra and to see what strategies the community had taken in demanding their land rights so that it was successful. Although it only explores 1 case of land conflict in Sarirejo, this research is expected to describe social conflict problems related to natural resources (land) in a more complex, holistic, and descriptive manner.

\section{Method}

This study used a qualitative approach with ethnographic methods to understand the background why Sarirejo people protect their land rights. The ethnographic method developed by James Spradley that produces descriptive data in the form of words or writings and the behavior of the people being observed (Spradley, 1997).

The data was collected data by field observations to identify the social situation of the community in Sarirejo Village. In addition, the researchers also conducted in-depth interviews and focus group discussions with key informants who was involved in the event, such as several community members and village officials. All of the obtained data was recapitulated, categorized, and then analyzed qualitatively.

\section{Results and Discussion}

The land conflict in North Sumatra began in the plantation era, where the Sultan of Deli, who was confirmed to be the ruler, gave concessions to plantation entrepreneurs (undermining) for lands belonging to the Malays. The initial crop that was planted was tobacco. The cultivation of tobacco seems to have disrupted the agricultural processing of the Malays. In order not to interfere, then the Jaluran Land Institute was created. After planting tobacco, the former tobacco plant land (land of the Jaluran) was given to Swapraja (kingdom) and self-government assigned the regional head to distribute Jaluran land to residents. After the planting activity is over, the land is returned back to the plantation entrepreneur. The recipients of the land were not only indigenous people (Malay people) but also immigrants. In the 1950's, many foreigners began arriving.

The residency of East Sumatra, which at that time was part of the province of North
Sumatra, contained the largest agrarian disputes in the plantation area. In the pre-war era there were two large plantation companies in East Sumatra, namely DPV (Deli Planters Vereniging), which was a collection of tobacco plantations; and AVROS (Algemeene Vereniging van Rubberplanters ter Oostkust van Sumatra) is an association of tree plantations such as rubber and oil palm. In subsequent developments the two plantation companies were merged into one under the name AVROS. In 1952 - 1953, the problem of illegal occupation was a hot problem in East Sumatra. The factor that motivates them to occupy these lands is that they assume that owning plantation land is a very profitable thing because these lands must be fertile and suitable for planting any kind of crops.

North Sumatra is one of the provinces with the highest agrarian conflicts. Based on the records of the Hutan Rakyat Institute, there are 106 community groups that have been in conflict with plantations and industrial plantation forest companies, with an area of 346,648. some have conflicts with PTPN, some are with private companies / real estate entrepreneurs, some are with the TNI, some are even with the land mafia.

\section{Overview of Sarirejo Village}

Sarirejo Village is a division of Polonia Village. Previously, it was part of the Medan Baru District in accordance with Government Regulation Number 50 of 1991. Sarirejo Village has an area of approximately 260 hectares which is divided into 9 (nine) environments with the following boundaries:

- In the north, it is bordered by Sukadamai Village, Medan Polonia District.

- In the south, it is bordered by Pangkalan Mansyur Village, Medan Johor District.

- In the east, it is bordered by Sukadamai Village, Medan Polonia District.

- In the west, it is bordered by Babura River, Beringin Village, Medan Selayang District.

The largest population of Sarirejo in Medan Polonia sub-district reaches 27,875 (see Table 1).

Some of the people's livelihoods are entrepreneurs (building), traders, teachers, 
employees, the Air Force. Population data by religion:

$\begin{array}{ll}\text { Muslim } & : 24.783 \\ \text { Christians } & : 3,357 \\ \text { Catholics } & : 355 \\ \text { Hinduism } & : 658 \\ \text { Buddha } & : 58 \\ \text { Confucianism } & : 0 \\ \text { And others } & : 1\end{array}$

Number of populations based on education level:

Not yet school $: 6,711$

Did not complete elementary school: 1,934

Completed Elementary School : : : 4,066

Junior High School : 4,443

Senior High School $\quad: 10,351$

DIP II $\quad: 45$

DIP III $\quad: 473$

Strata I $: 1,110$

Strata II $: 75$

Strata III $\quad: 4$

\section{Objective facts of community existence}

The people of Sarirejo have controlled the land since 1948 with the objective condition that currently there is a dense residential area, equipped with various public facilities such as mosques, churches, monasteries, Puskesmas, public roads, PLN, PAM, Telkom and other facilities so that they have become an Independent, compact and complete residential areas, especially when viewed from a governmental aspect, and become an administrative area, namely Sarirejo Village.

In the Sarirejo area there is also a Sikh Gurwara Temple located on Jalan Mawar which is the largest temple in Southeast Asia. Sarirejo Village is the most densely populated sub-district among the 5 (five) sub-districts in Polonia sub-district, with 4500 households or more than 25,500 inhabitants. As supporting evidence and good faith from the community, it can be seen from the city government that they have received the payment of Land and Building Tax (PBB) that the community has made so far on the land they control by attaching proof of control. This proves that there is a direct legal relationship between the community and the land (Yusrizal and Lubis, 2018). The support of the city government is also evident from the side of the city government which has provided KTP, family card and other certificates proving that the community's existence has been registered administratively in the work area of the Medan city government.

The land that is controlled by an area of 260 hectares is claimed to be part of a 591.3 hectare land which is an asset of the Indonesian Ministry of Defence cq TNI-AU Lanud Medan which is registered in the State Wealth Inventory No. Registration 50506001 which is used as the area of the Medan Polonia air base.

\section{Basic community ownership}

The basis for the control of the Sarirejo community over the land where the Sarirejo people have controlled a land area of 260 ha located in Sarirejo sub-district since 1948 until now and there are no rights from other parties, except the statement of assets from the Danlanud Polonia TNI - AU.

Where the TNI -AU was granted Management Rights (HPL) based on the Decree of the Minister of Home Affairs No.01/HPL/DA/70 dated February 3, 1970, cancelled by Decree of the Minister of Home Affairs number 150 / DJA / 1982 dated September 8, 1982 with consideration whereas the granting of HPL over land which is an air base in Medan is inappropriate according to its designation and use, it is more appropriate for the land to be granted with usufruct rights for a period of time as long as the land is used for an Air Force Base.

Based on the Decree of the Minister of Home Affairs Number 150/DJA/1982 dated September 8, 1982, the Commander of the I Airspace Command of the Medan Air Base is welcome to apply for the Right to Use for Air Force Territory land provided that, among other things, the land to be granted use rights must be free from The existence of a third party on it and part of the land where the rights of other parties are objectively not required as an Air Force Base area will be excluded from the grant of use rights. However, the people of Sarirejo are of the opinion that the TNI -AU has never controlled land controlled by the community so that rights have never been issued on behalf of the Indonesian Ministry of Defence and Security. 


\section{Basic mastery of TNI - AU}

KSAP Decree No.23/P/KSAP/50 dated May 25,1950 , stated that originally the airfield and buildings that belonged to the field and equipment in the field were really needed to maintain the field belonged to the TNI-AU. The existence of the Minister of Defence Decree No. MP/A/705/57 dated 3 August 1957 decided that the commanders of the Medan Air Force base, Padang, Palembang, Makassar, Tasuka, Kupang, Husein Sastranegara to exercise their respective military power (SOB) in the area covering the air base area. area mentioned above, which area is the land area within a radius of 3 miles from the centre point of the runway for these bases.

The joint decree between the Medan City Military Commander and the Medan Air Force Base number 01/1958 dated 3 February 1958 determined that the Medan Air Force Base areas had the following boundaries:

$$
\begin{array}{ll}
\text { East side } & \text { : Deli River } \\
\text { West side } & \text { : Babura River } \\
\text { North side } & \text { : Jalan Merdeka / Jalan Mon- } \\
& \text { gonsidi }
\end{array}
$$

Sebelah Selatan: Gedung Johor/rel kereta api

During the lawsuit from the community, the Airforce submitted the land registration of the disputed land so it would be certified for Airforce to use it. Some of the lawsuit was won by the community, but the Airforce pleaded for cassation. The Supreme Court overruled the cassation. However, the BPN issued the landuse right certificate for 202,78 $\mathrm{Ha}$ of land in Sarirejo, in which some of the certified land was won by the community. The Supreme Court granted some of the community's lawsuit that the locals can work the land, but not as the owner of land based on the Medan Court ruling No.310/Pdt.G/1989/PN-Mdn on 8 May 1990 and then enforced by appeal decision through Medan Court Ruling no.294/PDT/1990/PTMDN on 26th September 1990 and Supreme Court Ruling No. 229/Pdt.G/1991 on 19 Mei 1995. Moreover, the land was not released from its use-right by The Defense Ministry or was not cleared from the National Asset.

There was no compensation from the Airforce to the locals following the airbase establishment. Even though the Sarirejo local de facto live in the area. They live and build their homes there, even though they don't have the land certificate as a valid and legal ownership proof.

\section{Community strategy to claim land rights}

To get calm, comfort and certainty, the public filed a civil lawsuit against the Indonesian Air Force Base Polonia/Suwondo. In 1989 the community filed a lawsuit for the donated land and the Medan District Court won the community. Furthermore, from 1990 to 1995, a lawsuit for land/residential areas was represented by 87 community members. The Supreme Court has rejected the appeal of the TNI AU Lanud through decision number 229/ K/ Pdt/1991 dated May 18, 1995, however in several meetings between the Sarirejo community members and the TNI-AU, the TNI-AU always said that the disputed land was wrong. object. The community is the cultivator as decided by the Supreme Court. The community won only 5.6 hectares of the 260 hectares. The Indonesian Air Force controlled the KSAP letter No.023/P/KSAP/50 dated May 25, 1950.

Due to the conflict of the locals with the Airforce that eventually to violence and victims from the locals, Sarirejo locals finally file a complaint of the conflict to the Komnas HAM (Human Rights National Commission), Republic of Indonesia Staff Office, Regional Representative Council, and other related government institutions. The locals sent the lawsuit to Komnas HAM at 25th May 2015 and then replied at 2nd February 2016. The commission asked for further information regarding the conflicts. The office of Presidential Staff was notified at 2019 and the office responded by inscribe the Dirjen Kekayaan Negara, Kementerian Keuangan (Directorate General of National Asset in Finance Ministry) to give the information regarding the state ownership status regarding the disputed land and its building.

The North Sumatra Regional Representative Council also helped in mediating the conflict to the Ministry of Internal Affairs, Presidential Staff office, and The Ministry of General affairs and Housing in 30 January to 2 February 2019. The Medan Mayor also mediated a meeting at 18 August 2016 to help resolve the ongoing conflict. 
The locals did a lot of demonstration to the National Land Agency to demand the Land-use certificate issue for the locals regarding the 260 Ha of land as ruled by the Supreme Court. The Supreme Court ruling was the basis of the local's demand but the Airforce denied the claim. The Airforce had registered the land as a National Asset in 1997.

The locals were assisted by Medan Local Court and a lawyer named Hamdani Harahap, S.H. They also looked for supports from NGOs like Lembaga Bantuan Hukum Medan (Medan Legal Aid Agency) and Kontras Sumut (North Sumatra Commission for Missing Persons and Victims of Violence), students, and Labor Organization in their effort.

During the trial process took place from 1989 to 18 May 1995 the Indonesian Air Force Register the disputed land so that it is certified for the status of usufruct rights of the Indonesian Air Force on March 26, 1995. Then after the Supreme Court rejected the Indonesian Air Force's cassation through the $229 \mathrm{~K} / \mathrm{Pdt} / 1991$ decision on May 18, 1995, National Land Agency (BPN) issued usufruct certificates for an area of 202, 78 ha of Sarirejo land on June 13,1997 , respectively with certificate number 02.01.04.0001 and Certificate number 02.01.07.04.0004 in which part of the land that has been certified by BPN has been won by the community.

Furthermore, for the injustice felt by the community, Poniah et al filed a lawsuit against the PTUN for the 30 hectares of land they occupied where the land was in the certificate area No. 02.01.07.04.0004 dated June 25, 1997. Finally, the PK-TUN Supreme Court canceled the certificate of the Regional Head of BPN North Sumatra Province through a decision of Reg.No.60 PK/TUN/2006 dated 11 February 2008.

Apart from struggling through court processes, the people of Sarirejo also made political efforts outside the court. The people of Sarirejo have been fighting for their land rights in order to obtain land certificates for decades but the application was rejected by the Medan City Land Office on the grounds that the land requested was an Indonesian Air Force asset with register number 50506001 . The dissatisfaction of the Sarirejo community caused the community to carry out a massive demonstration on December 3, 1007 and continued on January 7,2008 , which was followed by around 10,000 mobs who blocked Polonia airport for 3 hours and occupied the Medan city land office for 4 hours thus paralysing flights from inside and to overseas.

Regarding the struggle of the Sarirejo community, the Medan City DPRD supports the Sarirejo community's struggle where in 2005 a meeting with Commission II of the DPR RI, the Indonesian Ministry of Defence and BPN RI in Jakarta with the recommendation of the cabinet secretary coordinating the resolution of the Sarirejo case with the Coordinating Minister for Political, Legal and Security Affairs, Minister Agrarian \& Spatial Planning, TNI Commander, Minister of Home Affairs, Minister of StateOwned Enterprises and Minister of Finance with due observance of "Inkracht" decisions by the Supreme Court.

The Indonesian Regional Representative Council of North Sumatra also recommended that the Minister of Defence rectify the boundaries of the land mentioned in register number 50506001 because the 260 -ha land was never controlled by the Indonesian Air Force and that the Indonesian National Land Agency (BPN RI) issue a certificate of land rights to the Sarirejo community for the welfare of the community. Efforts made by the Sarirejo community through political or non-litigation channels are carried out by building a group that organizes the entire Sarirejo community. Hearings and lobbying with policy makers are not only held once or twice. Even many times to the national level.

In fighting for land rights, the people of Sarirejo experienced persecution against the chairman of the Sarirejo Community Forum and a mother who was allegedly committed by the Indonesian Air Force Paskhas. This incident occurred on May 3, 2015, when the Paskhas elements carried out the persecution accompanied by threatening words that were racist in tone. For this action, the head of the Sarirejo Community Forum made complaints to the National Commission on Human Rights, the Witness and Victim Protection Agency (LPSK), and the Indonesian Air Force Military Police. 
What the community wants is that the land that was occupied by their previous parents can be handed over by the government to the Sarirejo community and can be certified. Because there has been a decision of the Medan District Court No.310/Pdt.G/1989/PN. North Sumatra High Court Decision No.294/Pdt.G/1990/PT.MDN in favor of residents. Strengthened by the decision of the Supreme Court of the Republic of Indonesia regarding the rejection of the Indonesian Air Force's cassation No.229/Pdt.G/1991 dated May 18, 1995.

The litigation and non-litigation effort of the locals was not in vain. In July 2020, the President, through the Ministry of ATR BPN issued the policy to end the land dispute between the air force and the Sarirejo locals. There were many stakeholders in the coordination meeting initiated by the President in 11 March 2020, such as BPN, DPR RI, DPRD Provinsi Sumut, KSP, Komnas HAM, and they decided to remove the Airforce base to Langkat Regency. The President also mandated the all-related institutions to National Army, Police Force, BUMN, and local government to put all of the administrative documentation in order. The Ministry of Agraria and Land Use also asked to make a scheme to end the land-dispute cases. But the question still remain, how is the continuation of the built buildings near Sarirejo as they were transferred to the third parties.

The Airforce is not entirely lost in this case as the use-right is not yet released from the Defense Ministry and the status is still National Asset. As much as $302 \mathrm{Ha}$ of land was certified to the Air force while the rest $260 \mathrm{Ha}$ is still disputed by the locals. The locals only won some of the lawsuit in the court, specifically 5,6 $\mathrm{Ha}$ based on the Supreme Court ruling. The consequences of the removal of airbase to Langkat regency is not yet revealed as the removal is still in discourse by the time this research underwent (Sekretariat Presiden, 2020; Tribunnews, 2020).

\section{Conclusion}

The land conflict that occurred in Sarirejo Sub-district, Medan Polonia, is one of the land conflicts that occurred in Indonesia, especially in North Sumatra, which has a long resolution.
As a living space, land for the community has a very important value. The success of the Sarirejo community in fighting for land from the claim of the TNI - AU c / q state is a motivation and learning for people who are fighting for rights to land anywhere.

Organizational strategies and advocacy strategies through legal processes that are undertaken to win state claims to land can be a source of inspiration as well as a signal for many groups of people who are still struggling to defend their rights.

Efforts should be made to provide alternative solutions to land conflicts, especially land earmarked for infrastructure, so that neither party feels disadvantaged, especially those who have lived for decades or even hundreds of years in the area. The state must provide as much space as possible for the people to live comfortably and safely because land is their living space.

\section{References}

A book:

Chandra, T. 2019. 'Non-Litigation Process Land Dispute Settlement for Legal Certainty', Substantive Justice International Journal of Law, 2: 2, 177-94.

Ikhsan E. 2015. Konflik Tanah Ulayat. (Indonesia). Koentjaraningrat, K. 1984. Javanese Culture (Jakarta). Limbong, B. 2012. Land Conflict (Jakarta).

Naibaho, J. A. 2020. Perlindungan Hukum bagi tanah ulayat masyarakat adat kesultanan deli akibat nasionalisasi NV DELI MAATSCHAPPIJ. Jurnal Law Review, 20: 1 .

Nulhaqim S. A., M. Fedryansyah, and E. N. Hidayat. 2019. 'Community-based agrarian conflict resolution in farming communities in Genteng Village, Sukasari District, Sumedang Regency', Jurnal Kolaborasi Resolusi Konflik, 1: 2, 70-141

Rachman, N. F. 2013. 'Chain of explanation of chronic, systematic, and extensive agrarian conflicts in Indonesia', BHUMI: Jurnal Agraria dan Pertanahan, 37: 12, 1-14.

Saifuddin, A. F. 2006. Contemporary Anthropology A Critical Introduction to Paradigm (Jakarta).

Spradley J. P. 1997. Ethnographic Method (Yogyakarta).

Yusrizal Y. and M. Y. Lubis. 2018. 'Land conversion to the poor people in the perspective of utilitarianism theory by bentham', E3S Web of Conference, 52: 1, 00053. 
Link / URL:

Alexander H. B. 2020. Five Land Disputes Deemed Obstructing Development in North Sumatra (https://prop-

erti.kompas.com/read/2020/07/30/104723021/1 ima-sengketa-tanah-yang-dianggap-hambat-pembangunan-di-sumatera-utara)

Arumingtyas, L. 2019. End of Year Note: Agrarian Reform is Still Far from Expectations (https://www.mongabay.co.id/2019/12/31/catatan-akhir-tahun-reforma-agraria-masih-jauh-dariharapan/)

Merdeka.com. 2019. Tuntut Sertifikat, Ratusan Warga Geruduk Kantor BPN Sumut (https://www.merdeka.com/peristiwa/tuntutsertifikat-ratusan-warga-geruduk-kantor-bpn-sumut.html)

Okezone News. 2019. DPRD Medan: TNI AU Tak Berhak atas Tanah Sari Rejo. (https://jejakparlemen.id/rangkuman/Komisi2-Pengawasan-RDPKemenATRBPN-KakanwilSumut-Sengketa-Lahandi-Sari-Rejo)
People's Consultative Assembly Republic of Indonesia. 2020. People of the Republic of Indonesia Number IX/MPR/2001 concerning Agrarian Reform and Natural Resource Management (http://kpa.or.id/publikasi/baca/peraturan_kebijakan/21/TAP_MPR_No._IX/2001_Tentang_Pembaruan_Agraria_dan_Pengelolaan_Sumber Daya Alam)

Sekretariat Presiden. 2020. [VIDEO] Rapat Terbatas Percepatan Penyelesaian Permasalahan Pertanahan Sumatera

Utara (https://www.youtube.com/watch?v=64yzg0anN4)

Tribunnews.com. 2020. BPN Sumut Susun Skema Penyelesaian Masalah Sengketa Tanah Warga Sarirejo-TNI AU - Tribun Medan. (https://medan.tribunnews.com/2020/08/03/bpn-sumutsusun-skema-penyelesaian-masalah-sengketatanah-warga-sarirejo-tni-au) 